Original Research Paper

\title{
Pengembangan Bahan Ajar IPA Berbasis Inkuiri Terbimbing untuk Meningkatkan Literasi Sains
}

\author{
Baiq Sri Komala Sari ${ }^{1 *}$, A. Wahab Jufri ${ }^{1,2}$, Didik Santoso ${ }^{1,2}$ \\ ${ }^{1}$ Program Studi Magister Pendidikan IPA, Pascasarjana Universitas Mataram, Indonesia \\ ${ }^{2}$ Program Studi Pendidikan Biologi, Fakultas Keguruan dan Ilmu Pendidikan, Universitas Mataram
}

\author{
Article history \\ Received: May $31^{\text {th }} 2019$ \\ Revised: June $25^{\text {th }} 2019$ \\ Accepted: July $17^{\text {th }} 2019$ \\ *Baiq Sri Komala Sari: Master \\ Program Studi Magister \\ Pendidikan IPA, Pascasarjana \\ Universitas Mataram, \\ Indonesia; \\ Email: \\ bqsrikomalasari88@gmail.com
}

\begin{abstract}
The purpose of this study is to produce a product in the form of science teaching materials that can improve the scientific literacy of students. This research is included in research and development of education which is a method for producing certain products and testing the effectiveness of these products. The product developed was validated by experts consisting of 3 people. Learning tools that are validated are syllabus, lesson plans, and scientific literacy instruments. The results of the study show that the learning device in the form of syllabus shows an average of $3.9(78 \%)$ in the appropriate category, the Learning Implementation Plan (RPP) shows an average of $3.9(78 \%)$ in the feasible category, and the items show the average value is $4.1(82 \%)$ in the feasible category. Thus, inquiry-based science teaching materials developed in appropriate categories can be applied in learning. The results of the questionnaire response analysis of students showed that students' responses were very good for teaching materials because $77.8 \%$ of students were fluent that guided inquiry-based teaching material was interesting. In a large-scale trial, the $\mathrm{N}$-gain value obtained in the experimental class was 70.74 with high criteria.
\end{abstract}

Keywords: Science Teaching Materials; Guided Inquiry; Science Literacy

Abstrak: Tujuan penelitian ini adalah menghasilkan suatu produk berupa bahan ajar IPA yang dapat meningkatkan literasi sains peserta didik. Penelitian ini termasuk dalam penelitian dan pengembangan pendidikan yang merupakan suatu metode untuk menghasilkan produk tertentu dan menguji keefektifan produk tersebut. Produk yang dikembangkan divalidasi ahli yang terdiri dari 3 orang. Perangkat pembelajaran yang divalidasi berupa silabus, RPP, dan instrumen literasi sains. Hasi penelitian menunjukkan bahwa perangkat pembelajaran berupa silabus menunjukkan rata-rata sebesar 3,9 (78\%) dalam kategori layak, Rencana Pelaksanaan Pembelajaran (RPP) menunjukkan rata-rata sebesar 3,9 (78\%) dalam kategori layak, dan butir soal menunjukkan nilai rata-rata sebesar 4,1 (82\%) dalam kategori layak. Dengan demikian, bahan ajar IPA berbasis inkuiri yang dikembangkan dalam ketegori layak sehingga dapat diterapkan dalam pembelajaran. Hasil analisis angket respon peserta didik menunjukkan bahwa respon peserta didik sangat baik terhadap bahan ajar karena $77,8 \%$ peserta didik bernggapan bahwa bahan ajar berbasis inkuiri terbimbing menarik. Pada ujicoba skala luas, nilai N-gain yang diperoleh pada kelas eksperimen sebesar 70,74 dengan kriteria tinggi.

Kata Kunci: Bahan Ajar IPA; Inkuiri Terbimbing; Literasi Sains

\section{Pendahuluan}

Bahan ajar merupakan komponen yang tidak dapat dipisahkan dari suatu proses pembelajaran. Bahan ajar dibuat agar peserta didik mampu mendapatkan informasi yang sesuai dengan tagihan kompetensi yang sudah disusun sedemikian rupa dalam kurikulum yang berlaku di suatu sekolah.

Khusus dalam pembelajaran IPA, bahan ajar yang ada belum cukup memfasilitasi peserta didik untuk menggali informasi dalam proses pembelajaran dan juga belum cukup membantu 
pendidik menyampaikan hal-hal yang bersifat esensial yang harusnya diketahui peserta didik sebagai awal melakukan proses pembelajaran.

Berkaitan dengan sains, banyak permasalahan yang harus dihadapi oleh peserta didik (Adholpus, \& Arokoyu, 2012) dan melalui proses pembelajaran, permasalahan tersebut bisa diatasi. Kemampuan peserta didik menggunakan pengetahuan sains sehingga mampu mendefinisikan permasalahan sampai pada akhirnya membuat keptusan dinamakan dengan literasi sains (OECD, 2013). Namun pada kenyataannya, sampai saat ini kemapuan literasi sains peserta didik masih sangat rendah. Hal ini sesuai dengan hasil beberapa penelitian yang menyatakan bahwa kemampuan literasi sains peserta didik masih tergolong rendah (Rifqiyati, 2013; Sulistiwati, 2015; Diana, 2015).

Melakukan pembelajaran sains merupakan salah satu cara untuk meningkatkan literasi sains (Gucluer \& Keserclioglu, 2012) dan salah satu pembelajaran sains yang telah banyak diterapkan adalah inkuiri (Wallace \& Kang, 2004; Salamon, 2007; Gormally, 2009; Seraphin, dkk., 2012). Inkuiri merupakan pembelajaran yang melibatkan peserta didik dalam kerja ilmiah seperti ilmuan sebenarnya (Tan \& Kim, 2012). Inkuiri memungkinkan peserta didik untuk menggunakan penalaran ilmiah dan pemikiran kritis untuk mengembangkan pemahaman tentang sains (Banerjee, 2010) serta keterampilan pemecahan masalah (Trna, dkk., 2012)

Pembelajaran sains dengan menggunakan pendekatan saintifik bersifat kontekstual sehingga langsung bersentuhan dengan kehidupan dan pengalaman nyata peserta didik, karena pada fase pengamatan peserta didik seyoganya diberikan fenomena yang sesuai dengan konteks peserta didik untuk memberi kesempatan kepada peserta didik menghubungkan konsep materi di sekolah dengan kehidupannya (Hosnan, 2014). Pendekatan saintifik dalam pembelajaran sains sangat cocok dengan teori konstruktivis sehingga pembelajaran menjadi lebih bermakna. Mengajarkan IPA dengan pendekatan saintifik juga berarti melatihkan keterampilan proses sains yang memfasilitasi peserta didik untuk memahami sains sebagaimana sains ditemukan dan mendorong peserta didik untuk menciptakan informasi ilmiah melalui penelitian ilmiahnya (Karar \& Yenice, 2012).

Komponen yang penting dalam proses pembelajaran adalah keberadaan bahan ajar bagi peserta didik (Mulyasa, 2006). Dalam meningkatkan kompetensinya, guru memerlukan berbagai bahan ajar, baik yang berupa, buku ajar, modul, dan LAIPD yang dapat membantu melaksanakan proses pembelajaran dengan baik dan lancar. Bahan ajar juga harus mampu menyajikan suatu objek secara terurut bagi keperluan pembelajaran dan memberikan sentuhan nilai-nilai afektif, sosial, dan kultural yang baik agar dapat secara komprehensif menjadikan peserta didik tidak hanya dapat mengembangkan kemampuan kognitifnya, tetapi juga afektif dan psikomotoriknya (Mulyasa, 2006).

Bahan ajar yang dapat dibuat oleh para guru dalam menyampaikan pembelajaran adalah 1) Modul; 2) LAIPD (Lembar Aktifitas Inkuiri Peserta Didik); 3) Diktat (Prastowo, 2011). Pengembangan bahan ajar sangat bermanfaat dalam proses belajar mengajar. Berdasarkan uraian di atas penulis termotivasi untuk melakukan penelitian pengembangan Bahan ajar. Bahan ajar yang dikembangkan mengacu kepada struktur dari bahan ajar secara umum meliputi: (1) Judul mata pelajaran, semester, dan tempat; (2) petunjuk belajar; (3) kompetensi yang akan dicapai; (4) indikator; (5) informasi pendukung dan langkahlangkah kerja; (6) tugas-tugas; (7) penilaian. Jadi bahan ajar yang dikembangkan harus memuat 7 struktur dari bahan ajar (Prastowo, 2011).

Bahan ajar yang telah ada dirasakan belum cukup untuk memfasilitasi peserta didik dalam menggali informasi dalam proses pembelajaran dan juga belum cukup dalam membantu pendidik menyampaikan hal-hal esensial yang harusnya diketahui peserta didik, sebagai awal melakukan proses pembelajaran khususnya dalam pembelajaran IPA. Pembelajaran mengacu pada kurikulum 2013 yang dijelaskan dalam Pedoman Mata Pelajaran IPA SMP tahun 2014 bahwa tema pengembangan kurikulum adalah agar menghasilkan insan yang produktif, kreatif, inovatif, melalui penguatan sikap, keterampilan, dan pengetahuan yang saling terintegrasi. Untuk memperkuat pendekatan ilmiah yang digunakan dalam Kurikulum 2013, maka perlu diterapkan suatu model pembelajaran yang sesuai dengan pembelajaran yaitu pembelajaran berbasis penyelidikan/peneletian, salah satunya adalah dengan bahan ajar berbasis Inkuiri.

Inkuiri merupakan pendekatan pembelajaran yang dapat diterapkan pada semua jenjang pendidikan (Sagala, 2007). Pembelajaran dengan pendekatan inkuiri sangat terintegrasi meliputi penerapan proses sains dengan proses berpikir logis dan berpikir kritis. Inkuiri merupakan pendekatan untuk memperoleh pengetahuan dan memahami dengan jalan bertanya, observasi, investigasi, analisis, dan evaluasi (Sagala, 2007).

Inkuiri telah terbukti sebagai pendekatan pembelajaran yang mampu mengembangkan berbagai kemampuan yang diperlukan oleh peserta didik. Hermansyah dkk. (2017) dan Yulianci (2017) mengungkapkan bahwa pembelajaran dengan 
pendekatan inkuiri terbimbing dengan bantuan multimedia berbasis komputer mampu meningkatkan penguasaan konsep mahasiswa. Suwandari (2018) juga menyatakan bahwa penerapan pendekatan inkuiri dapat meningkatkan keterampilan proses sains peserta didik. Kemampuan-kemampuan tersebut masih erat kaitannya dengan literasi sains, karena literasi sains memberikan kesempatan pada mahasiswa untuk mengembangkan kemampuan-kemampuan lainnya. Dan jika kemampuan-kemampuan tersebut mampu dikembangkan dengan baik menggunakan pendekatan inkuiri maka secara tidak langsung pendekatan ini sangat baik untuk mengembangkan literasi sains mahasiswa.

Materi pembelajaran sistem pencernaan dan sistem ekskresi merupakan salah satu materi yang sulit dipahami jika hanya dilakukan dengan pembelajaran searah dari guru, informasi yang akan didapatkan peserta didik sebatas pengetahuan guru mata pelajaran saja. Materi sistem Pencernanan dan sistem ekskresi juga merupakan materi yang kompleks, dimana materi yang tercakup didalamnya adalah sistem pencernaan manusia, sistem ekskresi. Selain itu, Materi sistem pencernanan dan sistem ekskresi ini dapat diterapkan pada kehidupan sehari-hari, dan dapat dikembangkan proses pembelajarannya dengan model pembelajaran inkuiri terbimbing. Membuat Materi sistem pencernanan dan sistem ekskresi manusia ini menjadi proses pembelajaran yang bermakna maka pengembangan bahan ajar dengan berbasis inkuiri terbimbing perlu dikembangkan untuk menunjang pembelajaran Abad 21 (Ledward \& Hirata, 2011).

Model pembelajaran inkuiri terbimbing adalah salah satu model pembelajaran yang terpusat pada peserta didik dimana dalam proses pembelajaran peserta didik dituntut aktif dalam melakukan pembelajaran, namun pada prosesnya guru tidak melepas begitu saja aktivitas peserta didik dalam proses pembelajaran, melainkan guru memberi bimbingan. Kendala penerapan Inkuiri terbimbing dalam pembelajaran diantaranya persiapan yang diperlukan harus lebih matang, waktu pembelajaran harus lebih panjang, dan bahan ajar yang memfasilitasi pembelajaran berbasis inkuiri masih terbatas. Kendala tersebut dapat diatasi dengan membuat sebuah produk bahan ajar yang berbasis Inkuiri terbimbing.
Hasil pengukuran literasi sains peserta didik tahun 2015 menunjukkan bahwa peserta didik sekolah menengah di Indonesia memiliki poin literasi sains yang rendah, walaupun mengalami kenaikan namun tidak signifikan bahkan bisa dikatakan tidak berubah sama sekali (PISA, 2012). Oleh sebab itu dilakukanlah penelitian Pengembangan bahan ajar berbasis inkuiri terbimbing dalam meningkatkan literasi sains peserta didik pada materi sistem pencernanan dan sistem ekskresi. Penelitian ini akan mendeskripsikan pengembangan bahan ajar berbasis Inkuiri terbimbing yang bertujuan untuk meningkatkan literasi sains peserta didik.

Berdasarkan uraian tersebut, maka peneliti mengadakan penelitian dengan tujuan menghasilkan suatu produk berupa bahan ajar IPA yang dapat meningkatkan literasi sains peserta didik sehingga dilakukan penelitian dengan judul pengembangan bahan ajar IPA berbasis inkuiri terbimbing materi sistem pencernaan untuk meningkatkan literasi sains.

\section{Metode}

Penelitian ini termasuk dalam penelitian dan pengembangan pendidikan (Educational Research and Developmen) yaitu suatu metode untuk menghasilkan produk tertentu dan menguji keefektifan produk tersebut. Penelitian dilakukan untuk membuat produk kemudian menguji keefektifan produk tersebut (Sugiyono, 2015). Produk yang dimaksud berupa bahan ajar IPA berbasis Inkuiri Terbimbing yang membantu meningkatkan literasi sains peserta didik. Pengembangan perangkat model pembelajaran dalam penelitian ini mengacu pada model pengembangan pembelajaran Dick \& Carey (2001) yang terdiri dari 10 tahap yaitu: (1) identifikasi tujuan pengajaran, (2) melakukan analisis pembelajaran, (3) analisis peserta didik dan konteks, (4) penetapan tujuan pembelajaran, (5) mengembangakan instrumen penilaian, (6) mengembangkan strategi pembelajaran, (7) mengembangkan media pembelajaran, (8) merancang dan melakukan evaluasi formatif, (9) melakukan revisi, (10) merancang dan melakukan evaluasi sumatif. 


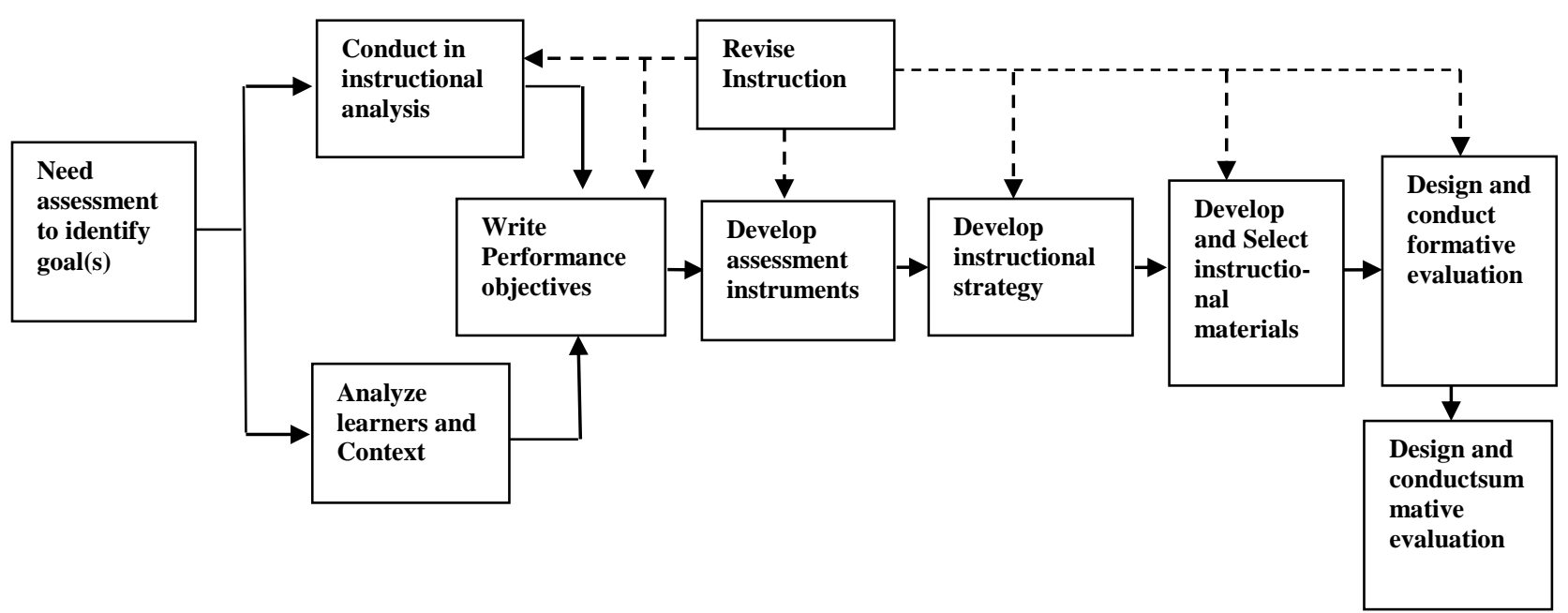

Gambar 1. Model Rancangan dan Pengembangan Pembelajaran (Dick and Carey, 2001).

Produk yang dikembangkan divalidasi tim ahli. Produk yang divalidasi adalah: 1) silabus, RPP, dan instrumen literasi sains. Data validasi dari ahli dianalisis secara kualitatif sebagai masukan untuk memperbaiki produk yang dikembangkan. Data angket mengenai tanggapan ahli terkait kelayakan produk pengembangan dianalisis dengan cara mentranspormasi skor rata-rata dari keseluruhan aspek yang diamati kedalam kalimat

\section{Hasil dan Pembahasan}

Perangkat yang dikembangkan dalam penelitian ini, terdiri dari: silabus, rencana yang bersifat kualitatif dengan kriteria seperti Tabel 1.

Tabel 1. Kriteria kelayakan bahan ajar

\begin{tabular}{ll}
\hline Kriteria kelayakan & Rentang rata-rata skor \\
\hline Tidak layak & $\geq 1,0-\leq 1,8$ \\
Kurang Layak & $1,8 \geq \mathrm{SV} \leq 2,6$ \\
Cukup Layak & $2,6 \geq \mathrm{SV} \leq 3,4$ \\
Layak & $3,4 \geq \mathrm{SV} \leq 4,2$ \\
Sangat Layak & $4,2 \geq \mathrm{SV} \leq 5,0$ \\
\hline
\end{tabular}

Sumber: Ratumanan \& Lauren ( 2011 )

pelaksanaan pembelajaran (RPP), dan tes literasi sains. Hasil validasi ahli untuk silabus dapat dilihat pada Tabel 2.

Tabel 2. Hasil Validasi Silabus

\begin{tabular}{llcccccc}
\hline \multirow{2}{*}{ No } & \multirow{2}{*}{ Aspek yang dinilai } & Validator 1 & Validator 2 & $\begin{array}{c}\text { Skor Validator } \\
\text { Validator 3 }\end{array}$ & $\sum$ & Rata-rata & Kategori \\
\hline 1. & Identitas Silabus & 4 & 4 & 4 & 12 & 4 & Layak \\
2. & Format Matriks Silabus & 3,9 & 3,7 & 3,9 & 11,4 & 3,8 & Layak \\
& Jumlah & & & & & 7,8 & 3.9 \\
& Rata-Rata & & & & & 3.9 \\
\hline
\end{tabular}

Berdasarkan Tabel 2, untuk perangkat pembelajaran berupa silabus menunjukkan rata-rata sebesar 3,9 (78\%) dalam kategori layak sehingga dapat disimpulkan bahwa perangkat pembelajaran yang dikembagkan seperti silabus layak untuk diterapkan dalam pembelajaran.

Tabel 3. Hasil Validasi Rencana Pelaksanaan Pembelajaran (RPP)

\begin{tabular}{llllllll}
\hline \multirow{2}{*}{ No } & \multirow{2}{*}{ Aspek yang dinilai } & \multicolumn{3}{l}{ Skor Validator } & & & \multirow{2}{*}{ Kategori } \\
\cline { 2 - 7 } & & Val. 1 Val. 2 & Val. 3 & $\sum$ & Rerata & Layak \\
\hline 1. & Identitas Sekolah, Mata Pelajaran, Kelas, Materi & 3.8 & 3.8 & 3.7 & 11.3 & 3.8 & Layak \\
& Pokok dan Alokasi waktu & & & & & & \\
2. & Kompetensi Dasar dan Indikator Pencapaian & 4.0 & 4.0 & 3.7 & 11.7 & 3.9 & Layak \\
& Kompetensi & & & & & & \\
3. & Tujuan Pembelajaran & 4.0 & 4.0 & 3.7 & 11.7 & 3.9 & Layak \\
4. & Materi Pembelajaran & 3.7 & 4.0 & 4.0 & 11.7 & 3.9 & Layak \\
5. & Metode, Media Pembelajaran dan Sumber Belajar & 4.2 & 4.0 & 3.7 & 11.8 & 3.9 & Layak \\
\hline
\end{tabular}

Pada perangkat pembelajaran untuk Rencana Pelaksanaan Pembelajaran (RPP) yang telah dikembangkan, terbagi dalam 4 kali pertemuan. Hasil validasi ahli seperti pada Tabel 3. 


\begin{tabular}{|c|c|c|c|c|c|c|c|}
\hline \multirow{2}{*}{ No } & \multirow{2}{*}{ Aspek yang dinilai } & \multicolumn{5}{|c|}{ Skor Validator } & \multirow{2}{*}{ Kategori } \\
\hline & & Val. 1 & Val. 2 & Val. 3 & $\sum$ & Rerata & \\
\hline \multirow[t]{3}{*}{6.} & $\begin{array}{l}\text { Langkah-Langkah Kegiatan Pembelajaran dan } \\
\text { Penilaian Hasil Belajar }\end{array}$ & 4.2 & 4.0 & 4.0 & 12.2 & 4.1 & Layak \\
\hline & Jumlah & & & & & 23.5 & \\
\hline & Rata-Rata & & & & & 3.9 & \\
\hline
\end{tabular}

Berdasarkan Tabel 2, untuk perangkat pembelajaran Rencana Pelaksanaan Pembelajaran (RPP) menunjukkan rata-rata sebesar 3,9 (78\%) dalam kategori layak sehingga dapat disimpulkan bahwa Rencana Pelaksanaan Pembelajaran (RPP) yang dikembagkan juga layak untuk diterapkan dalam pembelajaran.

Instrument tes literasi sains yang telah dikembangkan digunakan untuk mengevaluasi ketercapaian tujuan pembelajaran. Instrument tes ini dilengkapi dengan kisi-kisi dan kunci jawaban sebagai pedoman untuk mengevaluasi hasil jawaban peserta didik. Tes yang dikembangkan dalam bentuk pilihan ganda sebanyak 20 soal. Hasil validasi ahli dapat dilihat pada Tabel 4 berikut.

Tabel 4. Hasil Validasi Butir Soal

\begin{tabular}{|c|c|c|c|c|c|c|c|}
\hline \multirow{2}{*}{ No } & \multirow{2}{*}{ Aspek yang dinilai } & \multicolumn{5}{|c|}{ Skor Validator } & \multirow{2}{*}{ Kategori } \\
\hline & & Val. 1 & Val. 2 & Val. 3 & $\sum$ & Rerata & \\
\hline 1. & $\begin{array}{l}\text { Materi soal sesuai dengan KI dan KD yang } \\
\text { digunakan }\end{array}$ & 4 & 4 & 4 & 12 & 4.0 & Layak \\
\hline 2. & $\begin{array}{l}\text { Materi soal sesuai dengan indikator } \\
\text { pembelajaran }\end{array}$ & 4 & 4 & 4 & 12 & 4.0 & Layak \\
\hline 3. & $\begin{array}{l}\text { Kesesuaian pertanyaan dengan tingkatan } \\
\text { ranah kognitif }\end{array}$ & 4 & 4 & 5 & 13 & 4.3 & Sangat Layak \\
\hline 4. & Kejelasan redaksi kalimat yang digunakan & 4 & 4 & 4 & 12 & 4.0 & Layak \\
\hline 5. & $\begin{array}{l}\text { Kesesuaian soal dengan indikator literasi } \\
\text { sains }\end{array}$ & 4 & 4 & 4 & 12 & 4.0 & Layak \\
\hline 6. & $\begin{array}{l}\text { Kejelasan data (gambar, tabel, atau } \\
\text { sejenisnya) dengan inti pertanyaan }\end{array}$ & 4 & 4 & 4 & 12 & 4.0 & Layak \\
\hline 7. & Pengunaan bahasa sesuai dengan EYD & 5 & 4 & 4 & 13 & 4.3 & Sangat Layak \\
\hline \multicolumn{2}{|c|}{ Jumlah } & 29 & 28 & 29 & 86 & 28.7 & \\
\hline \multicolumn{2}{|c|}{ Rata-Rata } & 4.1 & 4.0 & 4.1 & & 4.1 & Layak \\
\hline
\end{tabular}

Hasil validasi soal pada Tabel 4 menunjukkan nilai rata-rata sebesar 4,1 (82\%) dalam kategori layak sehingga dapat disimpulkan bahwa butir soal yang dikembangkan layak untuk diterapkan dalam pembelajaran. Berdasarkan hasil pengamatan dan analisis data, produk bahan ajar IPA berbasis inkuiri terbimbing dapat dikategorikan layak untuk digunakan. Kelayakan tersebut didasari oleh 3 kriteria yang telah terpenuhi, yakni validitas silabus, rencana pelaksanaan pembelajaran, dan validitas butir soal. Melalui uji validasi ahli, bahan ajar IPA berbasis inkuiri terbimbing sudah valid sehingga dapat dikategorikan efektif dalam meningkatkan literasi sains peserta didik.

Dengan demikian, secara keseluruhan menunjukkan bahwa bahan ajar yang telah divalidasi oleh tim ahli dalam kategori layak sehingga dapat diterapkan dalam pembelajaran. Perolehan kriteria layak ini sesuai dengan hasil penelitian yang dilakukan oleh Zainuddin, dkk (2012) yang menyatakan, bahwa setelah melakukan tahap validasi, modul yang dikembangkan layak sebagai media pembelajaran dalam hal konten, kebahasaan, dan penyajian.

Uji coba terbatas bertujuan untuk mengetahui tanggapan peserta didik terhadap desain produk yang sebelumnya telah melalui revisi berdasarkan hasil validasi ahli dan praktisi. Uji coba terbatas dilakukan pada kelas VIII IPA di SMPN 1 Masbagik dengan jumlah 18 responden. Kegiatan uji coba dilakukan dalam pembelajaran IPA dimana peserta didik belajar dengan bahan ajar IPA. Di akhir kegiatan pembelajaran guru memberikan angket pada masing-masing peserta didik.

Angket berisi respon atau tanggapan dengan 13 buah pernyataan terkait Bahan ajar IPA. Peserta didik memberikan respon berupa jawaban skor 4 
Menarik, skor 3 cukup Menarik, skor 2 kurang Menarik, dan skor 1 tidak Menarik.

Tabel 5. Hasil Uji Terbatas Mengenai Respon Peserta Didik terhadap Bahan Ajar

\begin{tabular}{llrc}
\hline No & Aspek penilaian & $\sum$ Item & Persentase \\
\hline 1 & Menarik & 14 & $77,8 \%$ \\
2 & Cukup Menarik & 4 & $22,2 \%$ \\
3 & Kurang Menarik & 0 & $0 \%$ \\
4 & Tidak Menarik & 0 & $0 \%$ \\
\hline
\end{tabular}

Tabel 5 menyajikan hasil analisis angket respon peserta didik menunjukkan bahwa respon peserta didik sangat baik terhadap bahan ajar karena $77,8 \%$ peserta didik bernggapan bahwa bahan ajar berbasis inkuiri terbimbing menarik.

Uji efektifitas merupakan uji coba untuk mengetahui efektifitas bahan ajar IPA dalam menigkatkan literasi sains peserta didik. Bahan ajar IPA digunakan sebagai bahan ajar dalam model pembelajaran inkuiri terbimbing. Kegiatan uji coba dilakukan sesuai desain penelitian dimana terdapat dua sampel yaitu kelas eksperimen dan kelas kontrol. Di awal pembelajaran kedua kelas diberikan tes awal dengan instrumen tes literasi sains. Setelah mendapatkan perlakuan kedua kelas selanjutnya mendapatkan tes akhir dengan instrument yang sama saat tes awal. Hasil tes awal dan tes akhir ini dilakukan uji normalitas untuk megetahui distribusi data. Analisis akhir yaitu uji $\mathrm{N}$-gain untuk melihat peningkatan dari tes awal ke tes akhir. Hasil uji N-Gain untuk dedua kelas dijelaskan pada Tabel 6.

Tabel 6. Rekapitulasi Data Litearsi Sains

\begin{tabular}{|c|c|c|c|c|c|c|c|}
\hline No & Sekolah & Pre test & Post tes & Selisih & $\begin{array}{l}\text { Skor Maks- } \\
\text { Skor awal }\end{array}$ & N-Gain & Ket \\
\hline 1. & A (eksperimen) & 43.38 & 83.82 & 40.44 & 56.62 & 70.74 & Tinggi \\
\hline 2. & B ( kontrol ) & 40.23 & 73.44 & 33.20 & 59.77 & 54.1 & Sedang \\
\hline
\end{tabular}

Sebelum diterapkan pembelajaran dengan bahan ajar berbasis inkuiri terbimbing pada kelas eksperimen di SMPN 1 Masbagik, kemampuan literasi sains siswa termasuk dalam kategori sangat rendah dengan nilai rata-rata pretest sebesar 43,38. Namun, setelah dilakukan pembelajaran dengan bahan ajar berbasis inkuiri terbimbing niai literasi sains peserta didik meningkat dengan nilai rata-rata sebesar 83,82 dan termasuk dalam kategori baik. Nilai $\mathrm{N}$-gain yang diperoleh pada kelas eksperimen sebesar 70,74 dengan kriteria tinggi. Berbeda dengan hasil pada kelas kontrol yang proses pembelajaran tidak menggunakan bahan ajar berbasis inkuiri terbimbing, meskipun terjadi peningkatan namun peningkatannya tidak terlalu mempengaruhi hasil pretese sebelumnya dengan nilai $\mathrm{N}$-gain sebesar 55,1 dan termasuk dalam kriteria sedang.

Hasil analisis tersebut menunjukkan bahwa pembelajaran dengan bahan ajar berbasis inkuiri terbimbing sangat baik digunakan untuk meningkatkan literasi sains peserta didik. Inkuiri merupakan salah satu pembelajaran sains yang telah banyak diterapkan untuk meningkatkan literasi sains (Wallace dan Kang, 2004; Salamon, 2007; Gormally, 2009; Seraphin dkk., 2012). Hal ini karena model inkuiri terbimbing memfasilitasi guru dan membimbing peserta didik merencanakan dan membuat prosedur penyelidikan, melakukan penyelidikan ilmiah, menyusun hipotesis penelitian, berdiskusi secara kelompok, serta mengkomunikasikan hasil penelitian kepadatemantemannya.

Beberapa hasil penelitian menunjukkan kesamaan hasil dengan penelitian ini seperti Ngertini, dkk (2013) yang menyimpulkan hasl pelitiannya bahwa terdapat perbedaan literasi sains antara kelompok siswa yang mengikuti pembelajaran dengan model pembelajaran Inkuiri Terbimbing dibandingkan dengan kelompok siswa yang dipandu dengan model pengajaran langsung (Direct Instruction). Hasil penelitian Adi, dkk (2017) juga menyimpulkan bahwa Guided inquiry dan Blanded Learning (GI-BL) memiliki pengaruh yang signifikan dalam meningkatkan literasi sains.

Berdasarkan paparan tersebut, model pembelajaran inquiri terbimbing memberikan pencapaian pemamahan konsep lebih optimal dibandingkan dengan model pembelajaran langsung. Hermansyah dkk. (2019) juga mendukung hal tersebut bahwa penerapan inkuiri terbimbing mampu meningkatkan penguasaan konsep siswa. Tidak penguasaan konsep, penerapan inkuiri juga terbukti dalam meningkatkan keterampilan proses sains (Gunawan, dkk., 2019) dan kreativitas siswa (Wahyuni, dkk., 2019). Hal 
ini dikarenakan pembelajaran inkuiri terbimbing merupakan model pembelajaran yang berlandaskan pandangan Konstruktivisme yang memandang bahwa pembelajaran mengkonstruksi sendiri pengetahuannya. Pada pembelajaran Inkuiri terbimbing siswa mendapat petunjuk-petunjuk seperlunya, dapat berupa pertanyaan pertanyaan yang bersifat membingbing, Kemudian sedikit demi sedikit bimbingan dikurangi hingga siswa dapat bekerja mandiri dalam penyelesaian masalah.

Dalam pembelajaran inkuiri terbimbing sebagai pusat pembelajaran adalah siswa, dimana siswa dituntut untuk bertanggung jawab atas pendidikan yang mereka jalani serta diarahkan untuk tidak selalu bergantung pada guru. Pada pembelajaran inkuiri terbimbing siswa menjadi lebih termotivasi ketika mereka belajar menemukan sesuatu oleh dirinya sendiri, dari pada mendengarkan apa yang didkatakan guru. Mereka belajar melakukan aktivitas dengan otonomi dan menjadi yang inner-directed (Verawati, dkk., 2018). Bagi siswa yang inner-directed, penghargaan merupakan penemuan itu sendiri. Siswa belajar memanipulasi lingkungan lebih aktif. Mereka mencapai kepuasan dari pemecahan masalah, Bruner percaya bahwa siswa menerima sensasi Intelektual yang memuaskan suatu penghargaan intrinsic atau kepauasan sendiri.

\section{Kesimpulan}

Berdasarkan hasil validasi bahan ajar oleh validator ahli secara keseluruhan menunjukkan bahwa perangkat pembelajaran berupa silabus menunjukkan rata-rata sebesar 3,9 (78\%) dalam kategori layak, Rencana Pelaksanaan Pembelajaran (RPP) menunjukkan rata-rata sebesar 3,9 (78\%) dalam kategori layak, dan butir soal menunjukkan nilai rata-rata sebesar 4,1 (82\%) dalam kategori layak. Dengan demikian, bahan ajar IPA berbasis inkuiri yang dikembangkan dalam ketegori layak sehingga dapat diterapkan dalam pembelajaran. Hasil analisis angket respon peserta didik menunjukkan bahwa respon peserta didik sangat baik terhadap bahan ajar karena $77,8 \%$ peserta didik bernggapan bahwa bahan ajar berbasis inkuiri terbimbing menarik Pada ujicoba skala luas, nilai $\mathrm{N}$-gain yang diperoleh pada kelas eksperimen sebesar 70,74 dengan kriteria tinggi.

\section{Daftar Pustaka}

Adolphus, T., \& Arokoyu, A. A. 2012. Improving Scientific Literacy among Secondary School Students through Integration of Information and Communication Technology. ARPN Journal of Science and Technology, 2 (5):444-448.

Banerjee, A. 2010. Teaching Science Using Guided Inquiry as the Central Theme: A Professional Development Model for High School Science Teachers. Fall, 19 (2):1-9.

Diana, S. 2015. Penerapan Strategi Peer Assisted Learning (PAL) untuk Meningkatkan Kemampuan Literasi Sains Mahasiswa dalam Perkuliahan Fisiologi Tumbuhan. Laporan Penelitian Tidak Dipublikasi. Bandung: Departemen Pendidikan Biologi UPI.

Dick. W, Carey. L. Carey. J.O. 2001. The Systematic Design of Instruction. AddisonWesley Educational Publisher Inc.

Gormally, C., Brickman, P., Hallar, B., \& Armstrong, N. 2009. Effects of Inquirybased Learning on Students' Science Literacy Skills and Confidence. International Journal for the Scholarship of Teaching and Learning, 3 (2):1-22.

Gucluer, E., \& Kesercioglu, T. 2012. The Effect of Using Activities Improving Scientific Literacy on Students' Achievement in Science and Technology Lesson. International Online Journal of Primary Education, 1 (1):8-13.

Gunawan, G., Harjono, A., Hermansyah, H., \& Herayanti, L. 2019. Guided Inquiry Model Through Virtual Laboratory to Enhance Students'science Process Skills on Heat Concept. Jurnal Cakrawala Pendidikan, 38 (2), 259-268.

Hermansyah, H., Gunawan, G., \& Harjono, A. 2017. Pengaruh Penggunaan Laboratoium Virtual Dalam Pembelajaran Inkuiri Terbimbing Terhadap Penguasaan Konsep Kalor Peserta Didik. Jurnal Pendidikan Fisika dan Teknologi, 3 (2), 249-256.

Hermansyah, H., Gunawan, G., Harjono, A., \& Adawiyah, R. 2019. Guided inquiry model with virtual labs to improve students' 
understanding on heat concept. In Journal of Physics: Conference Series, 1153 (1), p. 012116.

Hosnan, M. 2014. Pendekatan Saintifik dan Kontekstual dalam Pembelajaran Abad 21. Bogor: Ghalia Indonesia

Karar, E. E. \& Yenice, N. 2012.The investigation of scientific process skill level of elementary education 8th grade students in view of demographic features. Procedia Social and Behavioral Sciences, 46, 3885-3889.

Ledward, B. C., \& Hirata, H. 2011. An Overview of $21^{\text {st }}$ Century Skill. Kamehameka School.

Mulyasa. 2006. Menjadi Guru Profesional Menciptakan Pembelajaran Kreatif dan Menyenangkan. Bandung: Penerbit PT Remaja Rosdakarya.

OECD. 2013. Education at a Glance 2013: OECD Indikators. OECD Publishing http://dx.doi.org/10.1787/eag-2013en.Diakses 15 Februari 2018.

Pisa. 2015. Draft Science Framework PISA 2015:www.oecd.org. Diakses 15 Juli 2018.

Prastowo, A. 2011. Panduan Kreatif Membuat Bahan Ajar Inovatif: Menciptakan Metode Pembelajaran yang Menarik dan Menyenangkan. Yogyakarta: DivaPress

Ratumanan, G.T. \& Laurens, T. 2011. Evaluasi Hasil Belajar pada Tingkat Satuan Pendidikan. Surabaya: UNESA University Press

Rifqiyati. 2013. Analisis Literasi dan Kemampuan Melakukan Mini Riset mahasiswa Biologi Universitas pendidikan Indonesia. Tesis tidak diterbitkan. Bandung: Universitas Pendidikan Indonesia.

Salamon, E. 2007. Scientific Literacy in Higher Education. University of Calgary: Commissioned by the Tamaratt Teaching Professorship.

Seraphin, K. D., Philippoff, J., Kaupp, L., \& Vallin, L. M. 2012. Metacognition as Means to Increase the Effectiveness of Inquiry-Based Science Education. Science Education International, 23 (4):366-382.

Sugiyono. 2012. Metode penelitian dan Pengembangan. Bandung. Alfabeta

Sugiyono. 2012. Metode penelitian dan Pengembangan. Bandung. Alfabeta
Sulistiwati. 2015. Analysis Understanding of Science Literacy Students Who Took Integrated IPA Course Using Sample Problem PISA 2009. Sainteks, 7 (1):21-40.

Suwandari, P. K., Taufik, M., \& Rahayu, S. (2018). Pengaruh Model Pembelajaran Inkuiri Terbimbing Terhadap Penguasaan Konsep dan Keterampilan Proses Sains Fisika Peserta Didik Kelas XI MAN 2 Mataram Tahun Pelajaran 2017/2018. Jurnal Pendidikan Fisika dan Teknologi, 4(1), 8289.

Tan, K. C. D., \& Kim, M. 2012. Issues and Challenges in Science Education Research. New York: Springer Dordrecht Heidelberg New York London.

Trna, J., Trnova, E., \& Sibor, J. 2012. Implementation of Inquiry-Based Science Education in Science Teacher Training. Journal of Educational and Intructional Studies in the World, 1(4):199-209.

Verawati, N. N. S. P., Wahyudi, \& Taufik. M. 2018. Efek dan Konstribusi Penggunaan Strategi Konflik Kognitif Berbasis Model Inkuiri Terhadap Peningkatan Kemampuan Berpikir Kritis Mahasiswa. Jurnal Pendidikan Fisika dan Teknologi. 4(2): 232-239

Wahyuni, S., \& Husein, S. (2019, June). Physics Learning Devices based on Guided Inquiry with Experiment to Improve Students' Creativity. Journal of Physics: Conference Series, 1233 (1), p. 012034.

Wallace C. S., \& Kang H. N. 2004. An Investigation of Experienced Secondary Science Teacher's Beliefs about Inquiry: An Examination of Competing Belief Sets. Journal of Research and Science Teaching, 41: 936-960.

Yulianci, S., Gunawan, G., \& Doyan, A. 2017. Model Inkuiri Terbimbing Berbantuan Multimedia Interaktif Untuk Meningkatkan Penguasaan Konsep Fisika Peserta Didik. Jurnal Pendidikan Fisika dan Teknologi, 3 (2), 146-154.

Zainuddin, M, \& Suyidno. 2012. Pengembangan Modul Fisika BumiAntariksa untuk Meningkatkan Prestasi Belajar Mahasiswa 
Prodi Pendidikan Fisika FKIP Unlam.

Jurnal Vidya Karya, 1 (1): 63-70. 